\title{
Reflexões sobre a responsabilidade civil do cirurgião-dentista
}

\author{
Reflections on the civil liability of the dentists \\ Reflexiones sobre la responsabilidad civil del odontólogo
}

\section{Victor COLUCCI NETO}

Pós-Graduação Lato Sensu em Direito Processual Civil pela UNAERP - Universidade de Ribeirão Preto-SP Graduação em Direito pela Universidade Paulista - UNIP campus de Ribeirão Preto-SP Advogado sócio do Escritório Colucci e Marques Advogados Associados

\section{Resumo}

O presente trabalho parte da teoria geral da responsabilidade civil no direito brasileiro e da apresentação dos seus conceitos principais, na sequência analisa o enquadramento da responsabilidade civil específica dos dentistas, a natureza da obrigação assumida pelo profissional perante os pacientes e expõe as possíveis implicações em casos de desempenho da atividade profissional com imprudência, negligência ou imperícia. Apresenta-se ainda uma análise de julgados realizados pelo Tribunal de Justiça do Estado de São Paulo nestes primeiros meses do ano 2019 e demonstra a importância da evolução e aprofundamento da pesquisa do tema no sentido de se buscar uma maior segurança jurídica quanto a controvérsias relevantes, notadamente sobre o enquadramento das obrigações como sendo de meio ou de resultado.

Descritores: Odontólogos; Responsabilidade Civil; Relações Dentista-Paciente.

\section{Abstract}

The present work is based on the general theory of civil liability in Brazilian law and on the presentation of its main concepts. It then analyzes the framework of specific civil liability of dentists, the nature of the obligation assumed by the professional towards patients and exposes the possible implications in cases of performance of professional activity with recklessness, negligence or malpractice. It also presents an analysis of judgments made by the Court of Justice of the State of São Paulo in these first months of 2019 and demonstrates the importance of the evolution and deepening of the research of the subject in the sense of seeking greater legal certainty regarding relevant controversies, notably on the framing of obligations as means or results.

Descriptors: Dentists; Damage Liability; Dentist-Patient Relations.

\section{Resumen}

El presente trabajo parte de la teoría general de la responsabilidad civil en el derecho brasileño y de la presentación de sus conceptos principales, en la secuencia analiza el encuadramiento de la responsabilidad civil específica de los dentistas, la naturaleza de la obligación asumida por el profesional ante los pacientes y expone las posibles implicaciones en casos de desempeño de la actividad profesional con imprudencia, negligencia o impericia. Se presenta además un análisis de juzgados realizados por el Tribunal de Justicia del Estado de São Paulo en estos primeros meses del año 2019 y demuestra la importancia de la evolución y profundización de la investigación del tema en el sentido de buscar una mayor seguridad jurídica en cuanto a controversias relevantes, especialmente sobre el encuadramiento de las obligaciones como de medio o de resultado.

Descriptores: Odontólogos; Responsabilidad Civil; Relaciones Dentista-Paciente.

\section{INTRODUÇÃO}

O presente artigo objetiva analisar a responsabilidade civil do profissional da odontologia no desempenho da sua atividade mediante uma análise bibliográfica, legislativa e jurisprudencial de casos concretos relevantes para a pesquisa.

$\mathrm{O}$ desenvolvimento das tecnologias, a intensificação da oferta de produtos e serviços dentre inúmeros outros fatores decorrentes da ampliação das relações sociais e profissionais, torna a sociedade mais suscetível à verificação de risco de danos pelos mais diferentes tipos de atividades, e as vítimas ou seus representantes legais têm questionado e buscado a respectiva reparação em dinheiro, como forma de indenizar o prejuízo, compensar a morte, a redução da capacidade de trabalho, a humilhação, a dor, a tristeza, o dano estético, enfim, diversos eventos que podem piorar a vida da pessoa de forma contrária ao direito.

A prestação de serviços de odontologia não está imune a esta realidade. $\mathrm{O}$ direito exige que os profissionais exerçam sua atividade segundo os preceitos legais e regulamentares, com as cautelas e precauções necessárias ao resguardo da vida e da saúde dos clientes, assegurando à vítima de erros profissionais o direito à reparação observadas as peculiaridades da legislação.

Em face do particularismo das diversas profissões e as respectivas prestações de serviços, inexiste um sistema geral igualmente aplicável a todas elas, de sorte que o estudo de cada profissão deve ser realizado individualmente, tal como se realiza neste artigo com relação à odontologia.

Aborda-se neste trabalho a específica responsabilidade civil dos dentistas, apresentando conceitos gerais necessários à melhor compreensão do tema, bem como realiza-se breve pesquisa empírica com análise de casos, apresentando alguns recentes julgados do Tribunal de Justiça do Estado de São Paulo envolvendo litígios entre pacientes e dentistas.

\section{REVISÃO DA LITERATURA E DISCUSSÃO \\ Generalidades sobre responsabilidade civil}

É importante distinguir o conceito de obrigação da noção de responsabilidade. Obrigação é sempre um dever jurídico originário, ao passo que responsabilidade é um dever jurídico sucessivo, consequente à violação do primeiro. Se alguém se compromete a prestar serviços profissionais a outrem, assume uma obrigação, um dever jurídico originário. Se não cumprir a obrigação, violará o dever jurídico originário, surgindo daí a responsabilidade, o dever de recompor o prejuízo pelo não cumprimento da obrigação ${ }^{1}$.

Essa distinção é feita pela literalidade do art. 389 do Código Civil Brasileiro ${ }^{2}$, segundo o qual, "não cumprida a obrigação, responde o devedor por 
perdas e danos, mais juros e atualização monetária segundo índices oficiais regularmente estabelecidos, e honorários de advogado".

Havendo um dano, produzido injustamente na esfera alheia, surge a necessidade de reparação como imposição natural da vida em sociedade, até para viabilizar sua própria existência e desenvolvimento, já que investidas ilícitas ou antijurídicas nos bens ou valores alheios perturbam o fluxo tranquilo das relações sociais de forma a exigir reações que o Direito engendra de forma a restaurar o necessário equilíbrio ${ }^{3}$.

Ao escolher as vias pelas quais atua na sociedade, o homem assume os ônus correspondentes, apresentando-se a noção de responsabilidade como corolário de sua condição de ser inteligente e livre.

A construção de uma ordem jurídica justa repousa em certas pilastras básicas, em que avulta a máxima de que a ninguém se deve lesar, de forma que se determinada atitude venha causar dano, injustamente, a outrem, cabe ao causador recompor a posição do lesado ou da forma devida mitigar os efeitos do dano, ao mesmo tempo em que seja sentido o peso da resposta compatível na ordem jurídica, do que se extraí que a natureza jurídica da responsabilidade será sempre sancionadora, independentemente de se materializar como pena, indenização ou compensação pecuniária. Clayton Reis ${ }^{4}$ :

Acerca da função da reparação civil, elucida

"O ofensor receberá a sanção correspondente consistente na repressão social, tantas vezes quantas forem suas ações ilícitas, até conscientizar-se da obrigação em respeitar os direitos das pessoas. Os espíritos responsáveis possuem uma absoluta consciência do dever social, posto que, somente fazem aos outros o que querem que seja feito a eles próprios. Estas pessoas possuem exata noção de dever social, consistente em uma conduta emoldurada na ética e no respeito aos direitos alheios. Por seu turno, a repreensão contida na norma legal tem como pressuposto conduzir as pessoas a uma compreensão dos fundamentos que regem o equilíbrio social. Por isso, a lei possui um sentido tríplice: reparar, punir e educar",

A responsabilidade civil possui deferentes modalidades e classificações, bem como conceitos relevantes para sua compreensão de forma que neste momento se apresenta um panorama geral para viabilizar adiante uma análise mais detida quanto aos aspectos que interessam à responsabilidade civil específica dos dentistas.

\section{- Responsabilidade civil subjetiva e objetiva}

A responsabilidade civil subjetiva é a decorrente de dano causado em função de ato doloso ou culposo. Esta culpa tem natureza civil e está regulamentada no art. 186 do Código $\mathrm{Civil}^{2}$, que preceitua que "aquele que, por ação ou omissão voluntária, negligência ou imprudência, violar direito e causar dano a outrem, ainda que exclusivamente moral, comete ato ilícito". A noção básica da responsabilidade civil nesta versão subjetiva é o princípio segundo o qual cada um responde pela própria culpa, de forma que, por se tratar de um fato constitutivo do direito à pretensão reparatória, caberá ao autor da pretensão sempre o ônus de provar a caracterização da conduta culposa.

Todavia, há situações nas quais o ordenamento jurídico atribui responsabilidade civil a alguém sem que seja necessária a caracterização da culpa, hipótese da Responsabilidade Civil Objetiva. Segundo esta espécie de responsabilidade, o dolo ou a culpa na conduta do agente causador do dano é irrelevante juridicamente, haja vista que somente será necessária a existência do elo de causalidade entre o dano e a conduta do agente responsável para que surja o dever de indenizar 5 .

Esta espécie de responsabilidade civil objetiva está relacionada à teoria do risco da atividade exercida pelo agente. Neste sentido, o parágrafo único do art. 927 do Código $\mathrm{Civil}^{2}$ estabelece que "haverá obrigação de reparar o dano, independentemente de culpa, nos casos especificados em lei, ou quando a atividade normalmente desenvolvida pelo autor do dano implicar, por sua natureza, riscos para o direito de outrem".

Segundo Venosa ${ }^{6}$ "todas as teorias e adjetivações na responsabilidade objetiva decorrem da mesma ideia. Qualquer que seja a qualificação do risco, o que importa é sua essência: em todas as situações socialmente relevantes, quando a prova da culpa é um fardo pesado ou intransponível para a vítima, a lei opta por dispensá-la”. A responsabilidade objetiva é uma noção mais protetiva, decorrente de uma evolução na história das responsabilizações para determinadas atividades com maior vulnerabilidade e risco potencial de danos, notadamente àquelas com benefícios econômicos para determinada categoria.

Como exemplos de responsabilidade civil objetiva, a qual se dispensa a prova da culpa do agente causador pode ser citada a ocorrência de danos ao trabalhador decorrente de acidente do trabalho, a responsabilidade da empresa exploradora de energia elétrica quanto a danos na transmissão, empresa vendedora de explosivos etc., sendo que nesta responsabilidade objetiva leva-se em conta o dano em detrimento do dolo ou culpa do agente causador.

As atividades são enquadradas na teoria do risco com base em dois fatores. Primeiro, há responsabilidade objetiva para aquelas atividades que o próprio legislador entendeu suficientemente arriscadas para se exigir a comprovação da culpa numa eventual busca indenizatória. São os casos, por 
exemplo, das relações de consumo, estipuladas no Código de Defesa do Consumidor ${ }^{7}$, da exploração de estradas de ferro (Dec. $n^{\circ}$ 2.681/12); a exploração da atividade aérea (Código da Aeronáutica - Lei $\mathrm{n}^{\circ}$ 1.565/86); a exploração de mineração (Código de Mineração - Dec.-Lei $n^{\circ}$ 277/67); transporte marítimo (Dec.-Lei $\mathrm{n}^{\circ}$ 116/67) e uso de veículos automotores (seguro de responsabilidade obrigatório - Dec.- -Lei no 73/66). Ainda, segundo a doutrina, se enquadrariam nessa categoria a responsabilidade do hoteleiro por furtos praticados por seus empregados contra hóspedes e a responsabilidade do banco que paga cheque falsificado (Súmula 28, STF). Em segundo, há a responsabilidade objetiva decorrente da adoção da teoria do risco pelo Código Civil (art. 927, parágrafo único, e art. 931, CC). Tem-se o risco como nexo de imputação da responsabilidade paralelo à culpa, não havendo dever de indenizar porque há um culpado, mas, sim, o dever de indenizar pela escolha legislativa de um responsável pela indenização ${ }^{8}$.

Aqui, há responsabilidade, mas não há ato ilícito. $\mathrm{O}$ ato é lícito e permitido, porém gera nível mais alto de risco pelo qual responde o causador, em atenção a um dever geral de proteção à coletividade, o risco produzido pelo ato é de inteira responsabilidade de seu causador. Note-se que o risco produzido deve ser originário da atividade exercida pelo agente de forma usual ou normal, ou seja, "o perigo deve resultar do exercício da atividade e não do comportamento do agente" .

Assim, vige no Brasil uma regra geral dual de responsabilidade civil, em que se têm a responsabilidade subjetiva, que é a regra geral, coexistindo com a responsabilidade objetiva, especialmente em função da atividade de risco desenvolvida pelo autor do dano verificável em cada caso concreto.

\section{- Responsabilidade Civil Contratual e Responsabilidade Civil Extracontratual}

Segundo o preceito fundamental neminem laedere, ninguém deve ser lesado pela conduta alheia, situação que se torna ainda mais grave quando a lesão decorre do descumprimento de uma obrigação contratual, espontaneamente assumida pelo infrator, em função da celebração de um negócio jurídico ${ }^{5}$.

Trata-se da diferença entre a responsabilidade civil contratual e a responsabilidade civil extracontratual, cujo enquadramento dependerá da norma jurídica violada no caso concreto.

A responsabilidade civil contratual decorre do inadimplemento ou violação de uma norma contratual anteriormente fixada entre as partes, ao passo que a responsabilidade civil extracontratual (também chamada "aquiliana") emerge da violação direta de uma norma legal por força da atuação ilícita do agente infrator, por exemplo, no caso do sujeito que colide seu carro com outro, a obrigação de reparar não decorre de vínculo contratual, mas sim de violação à lei.

A responsabilidade contratual está regulada nos artigos 389 e seguintes e 395 e seguintes do

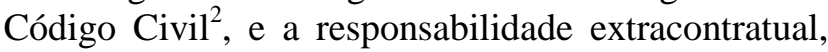
nos artigos 186 a 188 e 927 e seguintes do Código Civil. Nesta classificação o elemento subjetivo representado pelo conceito amplo de culpa nem sempre será indispensável, pois poderá haver responsabilidade civil independentemente da sua aferição.

Para caracterizar a responsabilidade civil contratual, como intuitivo, é necessário que a vítima e o autor do dano já tenham se aproximado e se vinculado para o cumprimento de uma ou mais prestações, sendo a culpa contratual a violação de um dever de cumprir o pactuado no negócio jurídico, ao passo que, na culpa aquiliana (extracontratual), viola-se um dever negativo, qual seja, a obrigação legal de não causar dano a ninguém.

Assim, no caso da culpa aquiliana (extracontratual), a culpa deverá ser sempre provada pela vítima, enquanto na responsabilidade contratual, ela é, em regra, presumida, invertendo-se o ônus da prova, cabendo à vítima comprovar, apenas, que a obrigação não foi cumprida, restando ao devedor o ônus de provar, por exemplo, que não agiu com culpa ou que ocorreu alguma causa excludente do elo de causalidade. $\circ$ Elementos relevantes para análise da
responsabilidade civil

Os elementos ou pressupostos gerais da responsabilidade civil são: conduta ou ato humano, nexo de causalidade e o dano ou prejuízo. A culpa não se caracteriza como elemento geral da responsabilidade civil, mas sim, um elemento acidental.

Menciona-se "conduta ou ato humano", e não apenas o ato ilícito - apesar deste ser a grande fonte da responsabilidade civil e obrigação de indenizar, pelo fato de existir hipótese de responsabilidade civil decorrente de atos lícitos, conforme já mencionado neste trabalho ao discorrer acerca da responsabilidade civil objetiva.

Os Atos ilícitos são os que promanam direta ou indiretamente da vontade e ocasionam efeitos jurídicos, mas contrários ao ordenamento. $\mathrm{O}$ ato voluntário é, portanto, o primeiro pressuposto da responsabilidade civil, conceito que se prende ao de imputabilidade, ou seja, a necessidade de que o agente seja juridicamente responsável. Trata-se, o ato ilícito, de um comportamento voluntário que transgride um dever ${ }^{6}$.

Culpa, por sua vez, consiste na inobservância de um dever que o agente devia conhecer e observar. Para Dias ${ }^{10}$ "a culpa é falta de diligência na observância da norma de conduta, isto é, o desprezo, por parte do agente, do esforço 
necessário para observá-la, com resultado não objetivado, mas previsível, desde que o agente se detivesse na consideração das consequências eventuais da sua atitude".

Como dito, o art. 186 do Código Civil ${ }^{2}$ elegeu a culpa como o centro da responsabilidade civil subjetiva que norteia a regra da responsabilidade civil no direito brasileiro.

A culpa, sob os princípios consagrados da negligência, imprudência e imperícia contém uma conduta voluntária, mas com resultado involuntário, a previsão ou previsibilidade e a falta de cuidado devido, cautela ou atenção ${ }^{6}$.

O Dano consiste na lesão a um interesse jurídico tutelado, material ou moral. Trata-se do único elemento obrigatório na responsabilidade civil. Para fins de responsabilidade civil trabalha-se com o "dano injusto", que é a lesão a um interesse concretamente merecedor de tutela. No que concerne aos reflexos da lesão a um determinado bem jurídico, pode o dano ser patrimonial ou extrapatrimonial.

O Dano patrimonial, lesão a um bem jurídico de conteúdo econômico, pode consistir em 'danos emergentes' - prejuízo efetivamente decorrente de um ilícito patrimonial, um empobrecimento da vítima, ou em 'lucros cessantes' - tudo aquilo que o ofendido, razoavelmente, deixou de auferir em razão da lesão, é o lucro certo frustrado. Como terceira espécie de dano patrimonial para alguns autores, ou subespécie de 'dano emergente' para outros como o destacam Farias e Rosenvald ${ }^{11}$, tem-se a 'perda de uma chance' que consiste na oportunidade dissipada de se obter futura vantagem ou de evitar o prejuízo em razão da prática de um dano injusto.

Dano extrapatrimonial ou moral decorre de lesão à dignidade da pessoa humana. Dignidade é fonte dos direitos fundamentais, como liberdade, igualdade, solidariedade, integridade psíco-física. Em regra, o descumprimento contratual não gera dano moral, salvo quando envolver valor fundamental protegido pela Constituição Federal (Enunciado n. 411, Conselho da Justiça Federal) ${ }^{12}$.

Neste tema, há que ser mencionado ainda o "Dano Estético", caracterizado pela lesão morfológica, desequilíbrio à imagem retrato, dano físico, traço distintivo do dano moral que se traduz em dano psíquico.

Já se entendeu que o dano estético estaria inserido no dano moral, todavia, vem sendo tratado como danos distintos pela doutrina e jurisprudência, o que está em conformidade com a crescente tendência de reconhecimento de novos danos. O STJ

- Superior Tribunal de Justiça consolidou esse entendimento na Súmula n. 387, de setembro de 2009, no sentido de que "é lícita a cumulação das indenizações de dano estético e dano moral". Trata-se de um reconhecimento relativamente recente, ou seja, por muito tempo os Tribunais não tutelaram esta espécie de dano.

Estes danos estéticos estão presentes quando a pessoa sofre feridas, cicatrizes, cortes superficiais ou profundos em sua pele, lesão ou perda de órgãos internos ou externos do corpo, aleijões, amputações, entre outras anomalias que atingem a própria dignidade da pessoa humana. Esse dano, nos casos em questão, será presumido como ocorre na responsabilidade objetiva ${ }^{13}$.

Nexo de causalidade é um elemento delicado da responsabilidade civil que consiste no vínculo ou liame que une a conduta humana ao respectivo resultado danoso, como uma consequência direta ou imediata, relação de causa e efeito. O Código Civil adota no art. 403 a teoria da causalidade imediata, segundo a qual responsabiliza-se pelo dano direto, que imediatamente decorre do fato.

Realizada esta breve análise sobre as generalidades e conceitos relevantes da teoria da responsabilidade civil, possível analisar-se a responsabilidade profissional do dentista.

Regulamentação legal da Odontologia

A Odontologia se dedica ao estudo e tratamento da boca, da gengiva, da dentição e do pavilhão que a abriga, sendo atividade reconhecida e regulamentada pela Resolução do Conselho Federal de Odontologia ${ }^{14}$ n. 63, de 2005, denominada "Consolidação das Normas para Procedimentos nos Conselhos de Odontologia" e suas respectivas alterações, que sistematizam e definem as especializações profissionais e os respectivos campos de atuação, assim como define e regulamenta as atividades complementares e integrantes da odontologia e os devidos registros administrativos.

A Lei 4.324, de 14.04.1964 instituiu o Conselho Federal e os Conselhos Regionais de Odontologia e o Decreto 68.704 de 1971 a regulamentou. Por sua vez, a Lei 5.081, de 24.08.1966 regula o exercício da odontologia.

Nos termos da legislação, tem se que para se tornar um cirurgião-dentista é necessário curso universitário específico em faculdade de odontologia, diploma de conclusão e inscrição no órgão de classe.

O Código de Ética Odontológica encontra-se previsto na Resolução do Conselho Federal de Odontologia n. 42, de 20.05.2003 e estabelece normas de conduta profissional, de proibição ou de obrigação e, ainda, o rol de prerrogativas individuais ou em grupos.

No decorrer desta análise nos deteremos de forma mais específica nos aspectos do Código Civil e do Código de Defesa do Consumidor que estabelecem a responsabilidade civil dos dentistas.

Responsabilidade civil do dentista

A obrigação que o dentista assume perante seu paciente, tal qual o médico, é espécie do gênero obrigação de fazer, em regra infungível, que pressupõe atividade do profissional, energia de 
trabalho, material ou intelectual, em favor do paciente. Implica em diagnóstico, prognóstico e tratamento: examinar, prescrever, intervir, aconselhar ${ }^{15}$.

O dentista realiza sua profissão com uma função personalíssima, escolha livre e com autonomia para praticar seus conhecimentos e desenvolver seu nome no mercado, o que acentua a preocupação com a responsabilidade pelos seus atos.

O Código Brasileiro de Defesa do Consumidor $^{7}$ (CDC), Lei 8078/90, trouxe a definição de profissional liberal em seu artigo 14, parágrafo $4^{\circ}$, que diz: "A responsabilidade pessoal dos profissionais liberais será apurada mediante a verificação de culpa".

A leitura deste artigo poderia dar a ideia de que apenas com a efetiva prova de culpa poderia se responsabilizar os profissionais liberais, ocorre que esse raciocínio poderia violar os princípios que decorrem de uma interpretação sistemática do CDC, que adotou a teoria do risco para as relações de consumo no sentido de que aquele que cria um risco para o consumidor a partir de sua atividade econômica, para a obtenção de lucro, deve indenizar os danos causados pelo produto ou serviço objeto desta atividade, de forma que a responsabilidade objetiva também poderá ser verificada em condutas de profissionais liberais.

Neste sentir, é de suma importância definir se a obrigação assumida pelo dentista perante seu paciente ou cliente, é uma "obrigação de meio" ou uma "obrigação de resultado", pois, desta definição é que haverá uma diferenciação sobre o ônus da prova da culpa em um processo judicial.

Explica-se por oportuno que as obrigações assumidas pelos profissionais liberais, quanto ao fim a que se destinam, podem ser "obrigações de meio" ou "de resultado".

A obrigação será de meio na hipótese em que o profissional (devedor da obrigação) se compromete a empregar seus conhecimentos, meios técnicos para a obtenção de determinado resultado, sem, no entanto responsabilizar-se por ele. É o caso, por exemplo, dos advogados, que não se obrigam a vencer a causa, mas sim a bem defender os interesses dos clientes de acordo com o emprego de todos os meios técnicos disponíveis; bem como o caso dos médicos, que não se obrigam a curar, mas tratar bem os enfermos, fazendo uso dos meios, consistentes em seus conhecimentos científicos.

Os profissionais mencionados no exemplo, advogado e médico, exercendo corretamente sua parte na prestação do serviço, farão jus à remuneração contratada pela prestação do serviço independentemente do resultado ser de êxito.

Quando a obrigação assumida pelo profissional liberal é definida como obrigação de resultado, o profissional (devedor da obrigação) dela se exonera somente quando o fim prometido é alcançado de fato, pois neste caso, o profissional se compromete com um resultado esperado e previsível. Não logrando êxito em atingir o resultado a que se comprometeu, o profissional é considerado inadimplente e obrigado a responder pelos prejuízos decorrentes do insucesso. Exemplo clássico de obrigação dessa natureza é a assumida pelo transportador, que promete tacitamente, ao vender o bilhete de passagem, levar o passageiro são e salvo a seu destino. Outro exemplo clássico é a obrigação do médico no caso da cirurgia plástica estética, há o compromisso com um resultado específico previsto ou esperado, ensejando obrigação de resultado.

$\mathrm{Na}$ obrigação de resultado, portanto, a não obtenção desse resultado importa o inadimplemento das obrigações assumidas e a responsabilidade pelo dano ocasionado. Não se eximirá da responsabilidade provando apenas ausência de culpa. Incumbe ao inadimplente o ônus de demonstrar que o dano se verificou por força maior, caso fortuito externo, culpa exclusiva da vítima ou, ainda, fato exclusivo de terceiro, exclusões da responsabilidade civil que serão vistas adiante.

Como já alertado, esta diferenciação entre obrigação de meios, ou de resultados, é vital para a solução de litígios judiciais envolvendo prestações de serviços odontológicos; se a obrigação é definida como de "meios", o paciente que ingressa com ação deverá comprovar culpa do dentista, desídia, provar que este não agiu com a melhor técnica devida, ou seja, será um processo que demandará um trabalho maior em busca da prova da imprudência, negligência ou imperícia do dentista; todavia, sendo a obrigação de resultado, a culpa é presumida mediante o fato do resultado não atingido, a entrega defeituosa, o insucesso em si que caracteriza o dever de indenizar, sendo neste caso, ônus do profissional provar que não agiu com culpa ou outra causa excludente da responsabilidade, como culpa da vítima.

Feita esta elucidação, pertinente agora nos debruçarmos a verificar se a responsabilidade do dentista é de meio, como a dos médicos em regra, ou responsabilidade de resultado.

Cavalieri Filho ${ }^{1}$ afirma peremptoriamente que a responsabilidade civil dos dentistas decorreria de uma obrigação de resultado, e justifica sua posição no fato de que os procedimentos de tratamento dentário são mais regulares, específicos, localizados. A obturação de uma cárie, o tratamento de um canal, a extração de um dente, são procedimentos que exigem uma técnica específica, mas que permitem se assegurar a obtenção de um resultado específico. Assim, segundo o jurista, ao desempenhar estas atividades o profissional odontólogo compromete-se com um resultado a entregar, e não apenas com a aplicação da melhor técnica e meios científicos. 
Todavia, no presente texto nos posicionamos no sentido de que não é possível ser afirmado que a obrigação assumida pelos dentistas seja de resultado, mas sim, que é necessário analisar cada caso concreto, pois existem situações complexas na rotina da odontologia nas quais o profissional não tem como prever e se comprometer com um resultado de êxito, casos em que assumirá obrigação de meios.

Kfouri Neto ${ }^{15}$ faz referência a um trabalho do Magistrado paulista Irineu Antonio Pedrotti que realizou um minucioso levantamento de eventos culposos mais comuns relacionados à odontologia que é digno de ser aqui transcrito ante a relevância para o fim de demonstrar que cada caso deve ser concretamente analisado para classificar a obrigação como de meio ou de resultado. Segue a transcrição:

"Assim, quanto ao cirurgião-dentista que exerce a odontologia social, denota culpa o erro no cálculo de concentração do flúor nas águas destinadas a consumo público, causando fluorese dental e, em casos extremos, intoxicações que podem conduzir ao óbito. O especialista em traumatologia bucomaxilofacial revelará culpa se provocar fratura e luxação mandibular ao extrair um dente retido. $\mathrm{Na}$ endodontia vislumbra-se culpa quando: a) na preparação de um canal provoca trepanação radicular, tanto pela falta de técnica como pela errônea interpretação radiográfica; b) dá ensejo à fratura de instrumento alargador (v.g., lima de instrumentação) no interior do conduto radicular, por excesso de uso ou motivo outro alheio à necessidade técnica. $\mathrm{O}$ ortodontista agiria com culpa ao não controlar a força aplicada para movimentação dental, ocasionando reabsorção radicular. Em odontopediatria, é culpado o destista que a) condena um elemento dental temporário, em vez de restaurálo (é que ele servirá de guia para o posicionamento do sucessor permanente.); b) extrai dentes temporários destruídos, mas com chance de recuperação através de prótese, provocando, posteriormente, distúrbio de oclusão na dentição permanente da criança. Especialista em prótese, denotará conduta culposa o dentista que 'instala prótese mal planejada, causando ao paciente problemas periodontais nas estruturas dentais remanescentes', ou que 'instala prótese mal planejada, onde o princípio da oclusão não foi respeitado, provocando distúrbios na articulação temporomandibular. $\mathrm{O}$ cirurgião-dentista especializado em radiologia agirá culposamente ao empregar técnica não apropriada ou não cuidar da boa técnica na revelação radiográfica, induzindo a erro na interpretação da radiografia e consequente falha de diagnóstico. O periodontista - que trada do periodonto, estrutura óssea e tecidos que sustentam os dentes, aí incluída a gengiva, cemento e ligamento periodontal - age com culpa ao não remover adequadamente os cálculos ou quando não instrui corretamente o paciente na remoção da placa, fator essencial à preservação da estrutura dental."
A transcrição supra, em verdade, não representa uma posição pacificada, mas sim, um levantamento realizado em estudo doutrinário, de forma que as hipóteses de culpa sugeridas deverão sempre ser analisadas em cada caso concreto.

Zuliani ${ }^{16}$ também esclarece que a obrigação assumida pelo dentista, poderá ser de meio ou de resultado, a depender da atividade, observando que "a prestação que o dentista assume, em situações convencionais do seu ofício (de menor complexidade, como obturação, limpeza, tratamento de canal) que correspondem aos serviços mais exigidos nos consultórios, é considerada como de resultado". O autor prossegue e ressalva a "situação de cirurgiões dentistas que assumem deveres para com acidentados, aceitando a improvável missão de recuperar o maxilar e a arcada dentária destroçados em um acidente grave (traumatologia bucomaxilofacial)". Entende que neste caso a obrigação seria apenas de meio ao esclarecer que "em tal hipótese a técnica perde a simplicidade que caracteriza o serviço de uma mera extração de dente, exigindo do profissional uma diligência que a ciência não garante o êxito" ${ }^{\prime 16}$.

Kfouri Neto ${ }^{15}$ exemplifica que, na odontologia, caracterizam-se como obrigações de resultado especialidades como a prótese dentária, dentística restauradora e a ortodontia. Assim, a responsabilidade dos dentistas poderá ser de meio, em atividades de maior complexidade e nas quais não é possível prever-se e comprometer-se com o êxito no resultado, como por exemplo, cirurgia de traumatologia decorrente de acidentes, mas também, no mais das vezes, será de resultados, como exemplo a contratação para correção da arcada dentária, tratamento de canal, limpeza, implantes ${ }^{17}$. Ressalvamos que sempre será possível análise de cada caso concreto para o correto enquadramento, não representando os exemplos mencionados rigor absoluto, mas sim a exposição daquilo que ordinariamente ocorre conforme exposição da doutrina referenciada.

Aliás, como exemplo dessa ausência de rigidez classificatória, enquanto Stoco $^{17}$ menciona implantes como obrigação de resultado, Kfouri Neto $^{16}$ considera expressamente a obrigação assumida pelo implantodontista como sendo de meios, e não de resultado e, ao discorrer sobre a "obrigação de meios" deixa claro sua posição:

"As consequências dessa afirmativa, no domínio da implantodondia ou implantologia são as seguintes: a) o dentista não se responsabiliza pelo insucesso do implante, caso tenha utilizado todos os meios disponíveis e, ainda assim, a osseointegração não tenha ocorrido de modo perfeito; b) a prova da culpa do dentista é atribuída àquele que busca a indenização (a própria vítima ou seus familiares); c) exatamente por se vincular a uma obrigação de 
meios, quase sempre milita em favor do dentista uma presunção de que o dano teria ocorrido de qualquer modo, desencadeado por uma causa inteiramente alheia à vontade do profissional e superior às forças deste, para tentar evita-la. Causa quase sempre endógena, tributável ao próprio organismo do paciente - e que foge ao controle do implantodontista"15.

Referido jurista prossegue realizando uma interessante análise do direito comparado de outros países no que tange ao tipo de responsabilidade do implantodontista, no seguinte sentido: na Itália, a implantologia gera obrigação de meios, quando reclama a solução de problemas técnicos de grande dificuldade e, quando se trate de intervenção de fácil execução, com resultado prejudicial ao paciente, a culpa seria presumida como obrigação de resultado; na Espanha, doutrina e jurisprudência consideram a obrigação contraída pelo dentista como sendo de meios, a não ser que se revista de natureza puramente estética; na França, esclarece que o princípio da obrigação de meios se aplica a todas as profissões da saúde, mas que existem algumas decisões que tratem a odontologia com mais rigor, como obrigação de resultado; na Argentina, a tendência jurisprudência é no sentido de considerar a colocação de próteses como uma obrigação de resultado, o que incluiria a colocação de implantes $^{16}$; e quanto ao Brasil, sua posição para enquadrar a implantodontia como obrigação de meios.

Convém salientar que o posicionamento de referido jurista está muito fundamentado quando menciona que a implantodontia se revista como obrigação de meios, o que difere de outras doutrinas analisadas. Esclarece que o implante cumpre uma função estética, posto que assuma forma e tamanho dos dentes naturais, e a função terapêutica, porquanto restabelece a função mastigatória do dente, e que o diagnóstico e exames prévios são decisivos para o êxito no tratamento - para excluir pessoas que não podem se submeter ao implante, bem como a qualidade dos materiais utilizados. Enfatiza que o atual estágio de desenvolvimento técnico e científico dos implantes situa a probabilidade de êxito ao redor de cem por cento, todavia, existindo uma pequena probabilidade de implantes malsucedidos sem que se possa atribuir ao especialista qualquer parcela de culpa, e por esta razão, conclui que não poderia enquadrar a implantodontia como uma obrigação de resultado $^{16}$.

Ressalva-se, por oportuno, que o presente artigo jurídico não tem pretensão alguma de adentrar na técnica da odontologia, mas contribuir para o estudo no sentido de apresentar a forma como é tratada a responsabilidade civil dos profissionais da odontologia pelos Tribunais e pela doutrina, apresentando as conclusões e julgados pertinentes, nos quais, por vezes poderá ser detectada alguma imprecisão quanto à menção de termos técnicosodontológicos, cuja escusa fica desde já ressalvada.

Convém mencionar que ao lado da odontologia propriamente dita, há profissionais auxiliares que, embora o produto do seu trabalho seja aplicado ao paciente, é ao dentista que se destina sua atividade, como por exemplo, o técnico em prótese dentária e o técnico de higiene bucal. Como a responsabilidade final é do dentista, sempre que houver responsabilidade destes profissionais, responderão eles, quando muito, solidariamente com o profissional principal, todavia, nada impede que um dentista responsabilizado perante o paciente, ingresse com ação regressiva contra o auxiliar ${ }^{7}$.

- Análise empírica de casos recentemente julgados pelo Tribunal de Justiça de São Paulo

Neste tópico do trabalho realizamos uma análise de casos julgados pelo Tribunal de Justiça do Estado de São Paulo, e optamos por delimitar a análise nos casos mais recentes, julgados entre janeiro/2019 e maio/2019 pelo Tribunal de Justiça do Estado de São Paulo, processos envolvendo dentistas e pacientes, conforme casos selecionados que se destacam para análise empírica que se apresenta de forma resumida. No Processo n. 102258814.2014.8.26.0577, proveniente da comarca de São José dos Campos-SP, data do julgamento 26/02/2019 no TJSP, tem-se o seguinte resumo da ementa de julgamento: Ação referente responsabilidade civil de dentista, com alegação de falha na prestação de serviço ortodôntico prestado à autora da ação. Autora que, após colocação de aparelho fixo, passou a sofrer com dores, infecção, sangramentos, sensibilidade, culminando com amolecimento e perda de dentes. $\mathrm{Na}$ hipótese dos autos a autora apresentava reabsorção óssea antes da colocação do aparelho, situação em que, conforme laudo pericial, o tratamento ortodôntico poderia agravar seu quadro. Réus (dentista e clínica) que não promoveram prévio controle e estabilização da doença periodontal antes da colocação do aparelho ortodôntico. Caracterização de defeito do serviço. Determinado o ressarcimento dos valores despendidos para realização do tratamento ortodôntico no valor de $\mathrm{R} \$ 3.831,00$. Danos morais caracterizados, determinado $\mathrm{o}$ pagamento de $\mathrm{R} \$ 30.000,00$.

No Processo n. 1004419-57.2015.8.26.0281, proveniente da comarca de Itatiba-SP, data do julgamento 12/02/2019 no TJSP, tem-se o seguinte resumo da ementa de julgamento: Pedido de indenização fundado no erro em tratamento odontológico, referente a Implante dentário. Concluiu-se tratar de Obrigação de resultado. Autora foi submetida a duas cirurgias para a colocação de próteses dentárias na parte superior (maxila) e inferior (mandíbula) da boca. Falta de osseointegração dos implantes. A defesa do dentista alegou culpa exclusiva da vítima em decorrência de 
tabagismo e higiene bucal precária. Todavia, Laudo pericial apontou que tais fatores não são determinantes para a ausência de osseointegração, podendo ser meros coadjuvantes. Ademais, o perito enfatizou, veementemente, que a paciente não foi informada sobre os riscos inerentes ao procedimento. Direito à informação corresponde a um dever anexo decorrente da boa-fé objetiva inerente às relações contratuais. Profissional não apresentou termo de consentimento informado e relatório cirúrgico pormenorizado, os quais conduzem à boa prática odontológica. Prestação deficitária dos serviços caracterizada. Demonstração do nexo de causalidade entre o apontado evento danoso e a conduta dos profissionais. Os réus cirurgiões-dentistas foram condenados à reparação por danos materiais (devolução das quantias pagas), por se tratar de obrigação de resultado. Danos morais caracterizados foram condenados ao pagamento de $\mathrm{R} \$ 30.000,00$ (trinta mil reais). Neste caso os dentistas possuíam um seguro, e a seguradora foi condenada a ressarcir os prejuízos nos termos e limites do contrato de seguro estipulado entre as partes, exceto riscos excluídos. No Processo n. 400258993.2013.8.26.0048, proveniente da comarca de Atibaia-SP, data do Julgamento 26/02/2019 no TJSP, tem-se o seguinte resumo da ementa de julgamento: Trata-se de ação de indenização por erro na prestação de serviços odontológicos, contrato verbal para colocação de próteses fixas. Laudo do IMESC constatou a instalação das próteses superiores em volume ósseo inadequado e a inobservância das regras odontológicas estabelecidas pela literatura científica. Defeito de serviço caracterizado. Houve queda e necessidade de remoção das próteses fixadas na parte superior. Foi determinado o ressarcimento dos valores gastos pelo paciente para reparação do erro, limitados a $\mathrm{R} \$ 10.000,00$ conforme laudo pericial. Além disso, houve condenação por dano moral no valor de $\mathrm{R} \$ 15.000,00$ com correção monetária e juros de mora, pois o paciente foi submetido a procedimento com erro que acarretou por vários meses debilidade mastigatória $\mathrm{e}$ necessidade de nova intervenção. $O$ julgamento não concedeu indenização por dano estético, por falta de prova de transformação morfológica que acarrete repugnância ou vexame.

Proveniente da comarca de São Paulo-SP, o Processo n. 1026829-73.2015.8.26.0002, data do julgamento 25/04/2019 no TJSP, tem-se o seguinte resumo da ementa de julgamento: Nesta ação de indenização ficou reconhecido que se trata de obrigação de resultado a colocação de próteses ou implantes, que houve erro e dano neste caso, conforme consta da sentença a prótese causava dor, desconforto e não correspondia ao tamanho da arcada, bem como não se provou realização prévia de exames. A clínica ré foi condenada a ressarcir danos materiais no valor de $\mathrm{R} \$ 3.425,30$ e ao dano moral fixado em $\mathrm{R} \$ 3.000,00$. No Processo n. 100050180.2016.8.26.0161, proveniente da comarca de Diadema-SP, Data do julgamento 26/03/2019 no TJSP, tem-se o seguinte resumo da ementa de julgamento: Trata-se de ação de indenização, na qual a perícia concluiu que houve erro no tratamento de canal, endodontia, o material aplicado ultrapassou o comprimento do canal do dente e penetrou o eixo maxilar, que causou a perda de um dente (segundo molar). Dano moral fixado em R\$ 15.000,00.

No Processo n. 1003966-48.2014.8.26.0006, proveniente da comarca de São Paulo-SP, Data do julgamento 22/04/2019 no TJSP, tem-se o seguinte resumo da ementa de julgamento: Trata-se de ação de indenização, na qual ficou reconhecida a responsabilidade civil subjetiva, tendo restado provada a culpa do dentista na modalidade imperícia, como fator causador das dores e problemas dentários. Autora fez vários retornos à clínica do réu; existência de diagnóstico feito por outro dentista que, à época dos fatos, indicava a necessidade de cirurgias periodontais e restaurações nos mesmos dentes objetos do tratamento realizado pelo réu. Autora que, no mais, tinha dores antes do tratamento com o réu e que continua com problemas dentários na mesma região objeto de intervenção cirúrgica. Houve condenação em ressarcir dano material no valor de $\mathrm{R} \$ 15.073,96$ referentes a gastos que a autora teve com tratamento de urgência em outra clínica, bem como condenação pelo dano moral fixado em $\mathrm{R} \$$ $6.000,00$.

No Processo n. 1018258-76.2016.8.26.0003, proveniente da comarca de São Paulo-SP, data do Julgamento 03/04/2019 no TJSP, tem-se o seguinte resumo da ementa de julgamento: trata-se de ação de indenização referente a erro no implante realizado, que acarretou dores, afrouxamento e hemorragia. Clínica e franquia condenadas a pagar indenização por dano material de $\mathrm{R} \$ 5.950,00$ e indenização pelo dano moral de $\mathrm{R} \$ 10.000,00$, com as correções devidas. No Processo n. 0006384-20.2008.8.26.0609, proveniente da comarca de Taboão da Serra-SP, data do julgamento 23/09/2019 no TJSP, tem-se o seguinte resumo da ementa de julgamento: trata-se de ação de indenização referente a erro de tratamento odontológico, consistente em problemas com extração de dois dentes para manutenção de aparelhos. Foi comprovada a culpa com perícia. Condenou-se ao pagamento de indenização equivalente a devolução da quantia paga $\mathrm{R} \$ 3.126,40$ com atualização desde o desembolso (2007) e juros de mora desde a citação par ao processo, bem como dano moral no valor de $\mathrm{R} \$ 7.000,00$ também com as correções devidas.

No Processo n. 1076847-95.2015.8.26.0100, proveniente da comarca de São Paulo-SP, data do julgamento 26/03/2019 no TJSP, tem-se o seguinte 
resumo da ementa de julgamento: Ação de indenização por tratamento que resultou na ausência de diversos dentes, presença de debilidade da função mastigatória, estética e fonética, instalação de próteses com qualidade não satisfatória, implantação de cilindros sem a quantidade de osso suficiente, acarretando a perda do implante. Defeito de serviço caracterizado. Devolução da quantia paga pelo consumidor determinada no importe de $\mathrm{R} \$ 46.233,59$ e indenização pelo Dano moral no valor de $\mathrm{R} \$$ 20.000,00 tudo com as correções e juros devidos.

No Processo n. 0019664-39.2013.8.26.0009, proveniente da comarca de São Paulo-SP, data do julgamento 12/03/2019 no TJSP, tem-se o seguinte resumo da ementa de julgamento:

Ação de indenização referente à extração indevida de um dente, da qual resultou alveolite com osso exposto e comunicação para o seio nasal e perda óssea. Necessidade de correção cirúrgica posterior. Sequelas permanentes. Acionamento da operadora do plano e da dentista. Condenação nos danos materiais $\mathrm{R} \$ 713,00$ no dano estético $\mathrm{R} \$ 1.500,00$ e dano moral $\mathrm{R} \$ 9.540,00$.

Essa análise empírica de casos não é exaustiva, os 10 casos acima apresentados foram selecionados com a finalidade permitir uma melhor visualização prática da teoria da responsabilidade civil do profissional dentista nos casos concretos. Nesta toada de análise empírica, selecionamos também casos julgados favoravelmente ao profissional dentista, afastando sua obrigação de indenizar.

Assim, o Processo n. 100216097.2017.8.26.0191, proveniente da comarca de Ferraz de Vasconcelos-SP, data do julgamento 17/04/2019 no TJSP, tem-se o seguinte resumo da ementa de julgamento: Ação que pedia indenização por Danos materiais e morais sob alegação de erro na confecção de prótese dentária. Responsabilidade subjetiva. Conjunto probatório que não logrou demonstrar a existência de negligência, imprudência ou imperícia no tratamento da paciente. Perícia que apontou a inexistência de erro técnico e o comprometimento da profissional em solucionar os problemas de adaptação com a prótese. A perícia judicial esclareceu que o fato de existir dificuldade de adaptação com a prótese era esperado, pois a paciente usava outra anteriormente, que possuía mordida cruzada; propor tratamento reabilitador com eliminação da mordida cruzada para melhores relações condilares e maxilomandibulares, não representa um erro técnico profissional. Ausência do dever de indenizar, ação julgada improcedente.

No Processo n. 0009605-07.2012.8.26.0565, proveniente da comarca de São Caetano do Sul-SP, data do julgamento 12/02/2019 no TJSP, tem-se o seguinte resumo da ementa de julgamento: Ação de indenização por danos materiais e morais por suposto erro em tratamento odontológico. Sentença que julgou improcedente o pedido de indenização. Alegações de complicações decorrentes de cirurgia de implantação de três próteses dentárias e reabsorção óssea. Todavia, não caracterização de erro no tratamento dentário. O Laudo pericial realizado permite a conclusão de que a reabsorção óssea é, no caso, risco inerente à própria cirurgia e que a conduta profissional foi consentâneo com os preceitos da prática odontológica. Afastado o pedido de indenização.

No Processo n. 1008902-24.2014.8.26.0554, proveniente da comarca de Santo André-SP, data do julgamento 27/03/2019 no TJSP, tem-se o seguinte resumo da ementa de julgamento: Ação de reparação de danos materiais e morais. Pleito fundado em erro praticado em cirurgia ortogmática. Sentença de improcedência. $\mathrm{O}$ ônus da prova dos fatos constitutivos de seus direitos que incumbia à autora do pedido. Laudo pericial indicativo de inexistência de nexo de causalidade entre a conduta do requerido e o resultado indicado pela autora. Exame pericial, ademais, que não concluiu por qualquer anormalidade na paciente. Inexistência de documentação ortodôntica anterior e posterior ao suposto evento danoso. Não se provou culpa profissional, de forma que o pedido foi julgado improcedente.

No Processo n. 1033415-92.2016.8.26.0002, proveniente da comarca de São Paulo-SP, data do julgamento 14/08/2014 no TJSP, tem-se o seguinte resumo da ementa de julgamento: Ação de indenização fundada em erro odontológico. Problemas advindos da colocação de prótese na arcada dentária superior da paciente. Prova pericial que atesta a regularidade e adequação do serviço prestado pela dentista, quadro de peri-implante que decorreu da negligencia com higiene bucal por culpa da paciente. Autora que desiste do tratamento, impedindo que o resultado satisfatório seja alcançado. Erro e defeito na prestação do serviço não caracterizados. Sentença de improcedência mantida.

No Processo n. 0002784-19.2015.8.26.0197, proveniente da comarca de Francisco Morato-SP, data do julgamento 22/02/2019 no TJSP, tem-se o seguinte resumo da ementa de julgamento: Pedido de indenização por Danos morais e materiais decorrentes de extração equivocada de dente, no sentido de que teria sido arrancado um dente sadio, ao invés do dente que casava dores. Inocorrência de erro por parte do profissional responsável pelo atendimento, ausência de prova neste sentido, pedido de indenização julgado improcedente.

No Processo n. 0000022-59.2012.8.26.0383, proveniente da comarca de Nhandeara-SP, data do julgamento 06/02/2019 no TJSP, tem-se o seguinte resumo da ementa de julgamento: Pedido de indenização por danos materiais e morais fundado em 
suposto erro de tratamento odontológico. Realizada a perícia no IMESC. Conclusão da prova técnica pericial indicou ausência de causalidade entre os fatos narrados na inicial e o achado clínico pericial. A perícia esclareceu que o tratamento foi finalizado sem constar qualquer anotação profissional de queixa. A paciente alega que fortes dores e anomalias na mordedura foram corrigidos por um outro profissional, mas, nos documentos de natureza odontolegal enviados pelo segundo profissional, não há indicação de erro do primeiro profissional. Pedido julgado improcedente.

Em conclusão, verificou-se que os julgados reafirmam a classificação da responsabilidade do dentista como subjetiva, com a classificação como obrigação de resultado e não de meio, em muitos casos, o que demonstra a necessidade de um aprofundamento da pesquisa e reflexões para se buscar uma maior segurança jurídica. Ressalta-se que a análise destes casos concretos, portanto, é relevante demonstrar a importância do tema pesquisado no dia a dia profissional, tema que deve ser tratado com atenção haja vista que está relacionado à vida e ao bem estar dos pacientes, bem como à construção da carreira do profissional.

\section{Excludentes da obrigação de indenizar}

Conforme foi possível verificar pela breve análise de casos apresentada, nem sempre problemas que acometam o paciente são atribuíveis à atuação em erro do profissional. Há casos em que inexiste o nexo de causalidade entre a conduta do profissional e os danos verificados.

Existe a hipótese, por exemplo, de exclusão da responsabilidade do profissional por culpa exclusiva da vítima, exemplo é quando o dentista indicar determinado tratamento para o paciente, e este não seguir as recomendações do profissional.

A culpa concorrente também é outra excludente, na qual a responsabilidade é tanto do dentista quanto do paciente. Há também o caso fortuito, quando o dano decorrer de algo imprevisto superior a vontade do homem e a força maior é quando se sabe que vai acontecer o fato, mas não pode evitá-lo.

Quando o paciente contrata com o dentista um tratamento exsurge uma obrigação para ambas as partes, com direitos e deveres. $\mathrm{O}$ ideal e recomendável é que essa relação decorra com transparência e que o profissional realize a informação clara sobre todos os riscos do tratamento contratado, e o consentimento do paciente em assumir os riscos do tratamento, de forma documentada e assinado por ambos e, no desempenho da sua atividade utilize sempre a melhor técnica em conformidade com a literatura científica.

Em suma, a responsabilidade existe tanto do profissional dentista como do paciente. O exercício de uma relação profissional transparente, com efetiva informação dos riscos, bem como emprego da melhor técnica ao caso seguida do cumprimento das recomendações do profissional pelo paciente, são elementos importantes para uma relação sem conflitos.

\section{CONCLUSÃO}

Objetivou-se com o presente trabalho realizar um levantamento doutrinário, legislativo e jurisprudencial acerca da análise da responsabilidade que envolve esta tão importante profissão dos dentistas, e com a análise de casos concretos julgados pelo Tribunal de Justiça, demonstrar que trata-se de relevante realidade digna de atenção e reflexão.

Como dito, a sociedade está cada vez mais acessível à informação e impulsionada, pela valorização da cidadania, em busca do reconhecimento de seus direitos. Na relação entre dentista e paciente há direitos e deveres recíprocos de forma que a responsabilidade civil do profissional é algo que precisa ser corretamente compreendida para evitar-se equívocos e injustiças.

Verificou-se que existem divergências doutrinárias sobre pontos relevantes, notadamente, na classificação da obrigação do dentista como sendo obrigação de meios ou de resultado, o que impacta profundamente no julgamento dos litígios em trâmite no Judiciário, e a consequente necessidade de uma evolução no sentido de se buscar uma maior segurança jurídica nesta questão.

E por fim, constata-se que restou evidenciada a grande necessidade de que os profissionais da odontologia cerquem-se de cuidados básicos, como ocorre em toda atividade profissional, certificando-se de corretamente informar seus pacientes acerca dos riscos de cada procedimento e deles obter um consentimento expresso, notadamente em casos mais complexos, bem como entregando ao paciente sempre a melhor técnica à que se comprometeu, haja vista que se trata de atuação profissional que lida com expectativas de saúde, autoestima e felicidade pessoal.

\section{REFERÊNCIAS}

1. Cavalieri Filho S. Programa de Responsabilidade Civil. 11. Ed. São Paulo: Atlas; 2014.

2. Brasil. Código Civil - Lei 10406 de 2002. Código Civil Brasileiro. Brasília, DF: Senado, 2002.

3. Bittar CA. Reparação Civil por Danos Morais, São Paulo: Revista dos Tribunais; 1993.

4. Reis C. Avaliação do Dano Moral, 3. ed., Rio de Janeiro: Forense; 2000.

5. Gagliano PS, Pamplona Filho R. Novo Curso de Direito Civil, volume 3: responsabilidade Civil. 14. ed. São Paulo: Saraiva; 2016.

6. Venosa SS. Direito Civil - Parte Geral. São Paulo: Atlas; 2003.

7. Brasil. Lei no ${ }^{\circ} .8 .078$, de 11 de setembro de 1990. 
Código de Defesa do Consumidor. Dispõe sobre a proteção do consumidor e dá outras providências. Disponível em: http://www.planalto.gov.br/ ccivil_03/Leis/L8078.htm.

8. Godoy CLB. Responsabilidade civil pelo risco da atividade. 2. ed. São Paulo: Saraiva, 2010.

9. Diniz MH. Curso de direito civil brasileiro. 16. ed. atual. de acordo com o novo Código Civil. São Paulo: Saraiva; 2002. v. 7.

10.Dias JA. Da Responsabilidade Civil. 6. ed. Rio de Janeiro: Forense; 1979.

11.Farias CC, Rosenvald N. Direito Civil - Teoria Geral. Rio de Janeiro: Lúmen Júris; 2007.

12.Brasil. Constituição Federal de 1988. Promulgada em 5 de outubro de 1988. Disponível em: http://www.planalto.gov.br/ccivil_03/constituicao/ constituição.htm

13. Tartuce F. Direito Civil: Direito das Obrigações e Responsabilidade Civil, 11. ed. Rio de Janeiro: Forense; 2016.v.2

14. Conselho Federal de Odontologia. Resolução n. 63, de 18/4/2005. Aprova a consolidação das normas para procedimentos em conselhos de odontologia. Diário Oficial da República Federativa do Brasil, Poder Executivo, Brasília, DF, Seção 1, 19/04/2005 p. 104

15.Kfouri Neto M. Responsabilidade civil do médico: responsabilidade civil do dentista, completo ementário cível e criminal, jurisprudência do CRM e planos de saúde, acórdãos cíveis na íntegra. Imprenta: São Paulo, Revista dos Tribunais; 2003.

16.Zuliani ES. Questões atuais da responsabilidade civil. ADV - Seleções Jurídicas. São Paulo: COAD, p. 3-34, ago-2004.

17. Stoco R. Tratado de Responsabilidade Civil. Doutrina e Jurisprudência. 9. ed. São Paulo: Revista dos Tribunais; 2013.v.1.

\section{CONFLITO DE INTERESSES}

O autor declara não haver conflitos de interesse.

AUTOR PARA CORRESPONDENCIA

Victor Colucci Neto

vitorcn@hotmail.com

Submetido em 01/03/2019

Aceito em 15/03/2019 